\title{
EFEITO DE ALGUNS CURARES NATURAIS E DA d-TUBOCURARINA RETARDANDO O TEMPO DE COAGULAÇÃO E O TEMPO DE PROTROMBINA DO SANGUE HUMANO ${ }^{1}$
}

JOÃO CANALI

Instituto Oswaldo Cruz, Rio de Janeiro, Guanabara

JOÃO VIEIRA

As afirmações de BANCRoFt, após observar os efeitos produzidos pelo curare elaborado pelos índios no sentido de ser o mesmo capaz de "enegrecer e liquefazer o sangue", afirmações estas que estão em concordância com o descrito por Nicolas Monard (Histoire des Simples et Medicaments Apportés de l'Amerique) e com as de Fontana ( Apud Bernard, C., 1857), e discordantes das observações feitas por C. BERNARD, B. Rodrigues (Apud Hoehne, F. C., 1939) e outĩos, levaram-nos a verificar êstes efeitos no sangue humano.

Utilizamos em nossas experiências 5 curares de datas e procedências diferentes bem como a D-Tubocurarina, todos referidos na Tabela II desta publicação. ${ }^{2}$

\section{TECNICA}

Iniciamos nossos estudos com a feitura de emulsões a $1 \% \quad(0,1 \mathrm{~g}$ em $10 \mathrm{~cm}^{3}$ de sôro fisiológico recém-preparado) de diferentes curares e da d-Tubocurarina as quais após filtração, foram centrifugadas e os sobrenadantes isolados para a utilização nos diferentes ensaios. Em seguida, testamos o efeito curarizante das diferentes emulsões por meio da clássica experiência de C. Bernard em B. crucifer. Isto feito, passamos à verificação do efeito destas emulsões sôbre tempo de coagu-

Recebido para publicação a 29 de novembro de 1966 .

Trabalho do Instituto Oswaldo Cruz (Divisão de Fisiologia e Farmacodinâmica, Seção de Farmacodinâmica) .

$=$ Os diferentes venenos ensaiados, excetuando-se o curare elaborado por indios Ticunas, e do cloridrato de d-Tubocurarina, foram-nos fornecidos pelo Sr. Alcuino Meyer, preparado por índios Makus", cujas tribus habitam as regiōes fronteiriças do Brasil com a Colômbia, e estavam acondicionados em potes de barro. O ano em que foram obtidos os diferentes venenos constam na Tabela II. Segundo Biocca (Arq. Biol. 30 : 134, 1946) no preparo dêsses curares não são utilizadas substâncias de origem animal ao contrário do que ocorre com os elaborados pelos Ticunas. 
lação do sangue humano. Adotamos em nossas experiências a técnica original de LEE-WHITE e o curare escolhido, nesta oportunidade, foi o elaborado pelos índios Ticunas. Emulsões de concentrações diferentes dêste veneno $(0,01 \%, 0,1 \%, 1 \%)$ foram prèviamente adicionadas aos tubos que iam conter os diferentes sangues dos doadores (4) na proporção de $0,5 \mathrm{~cm}^{3} \mathrm{em}$ cada tubo. Os resultados obtidos nestas experiências encontram-se referidos na Tabela I.

Uma vez realizadas as experiências acima referidas, e verificado que a emulsão a $1 \%$ era a que desempenhar a um efeito mais nítido, iniciamos nova série de experimentos pesquisando nesta oportunidade o efeito de diferentes curares e da d-Tubocurarina no tempo de protrombina de um dos doadores, por meio da técnica original de QUICK, sendo que nesta oportunidade a emulsão $(1 \%)$ contendo o curare na proporção de $0,1 \mathrm{~cm}^{3}$ era preliminarmente adicionada ao plasma sanguíneo $\left(0,1 \mathrm{~cm}^{3}\right)$ objeto da experimentação. Concomitantemente, pro. cedimento análogo, foi realizado com o plasma sanguíneo adicionado de $0,1 \mathrm{~cm}^{3}$ de sôro fisiológico. Por outro lado, também, o tempo de protrombina do plasma puro do mesmo doador foi registrado. Para cada um dêstes ensaios foram realizadas quatro verificações e as médias dos resultados obtidos, encontram-se referidas na Tabela II.

De acôrdo com o que acima ficou descrito, ensaiamos todos os curares do plasma sanguíneo de um só doador, e o curare elaborado pelos Ticunas, com o mesmo objetivo, no plasma sanguíneo de quatro doadores diferentes, cujos resultados podem ser vistos na Tabela III.

As amostras de sangue que foram utilizadas nos diferentes ensaios, foram obtidas através punçẫo venosa seguindo os preceitos das técnicas mencionadas, e os resultados obtidos foram submetidos à análise estatística segundo a fórmula:

$$
\mathrm{t}=\frac{\text { Diferença entre as médias }}{\text { Êrro padrão da diferença entre as médias }}
$$

\section{RESULTADOS}

De acôrdo com o que se pode ver na Tabela I, o curare elaborado pelos índios Ticunas na concentração a $1 \%$, determinou um efeito expressivo no tempo de coagulação do sangue humano, donde a escolha dessa concentração para a feitura das emulsões com os demais venenos. Limitamo-nos a pesquisar o efeito do veneno dos Ticunas no tempo de coagulação por ter sido êle o responsável por controvérsias no passado, conforme veremos mais adiante.

Os resultados do tempo de coagulação do sangue e do tempo de protrombina do plasma, respectivamente adicionado de $0,5 \mathrm{ml}$ e de $0,1 \mathrm{ml}$ de sôro fisiológico, serviram de têrmo de comparação (Testemunhas) para os diferentes ensaios realizados com as diferentes emulsões de curares. Também, para êstes ensaios-testemunhas, realizamos quatro verificações cujas médias, conforme pode-se ver nas respectivas Tabelas, nenhuma diferença significativa apresentaram com os resul- 
TABELA I

Efeitos produzidos pelas emulsões de curare preparado por Índios Ticunas no tempo de coagulação do sangue de indivíduos diferentes

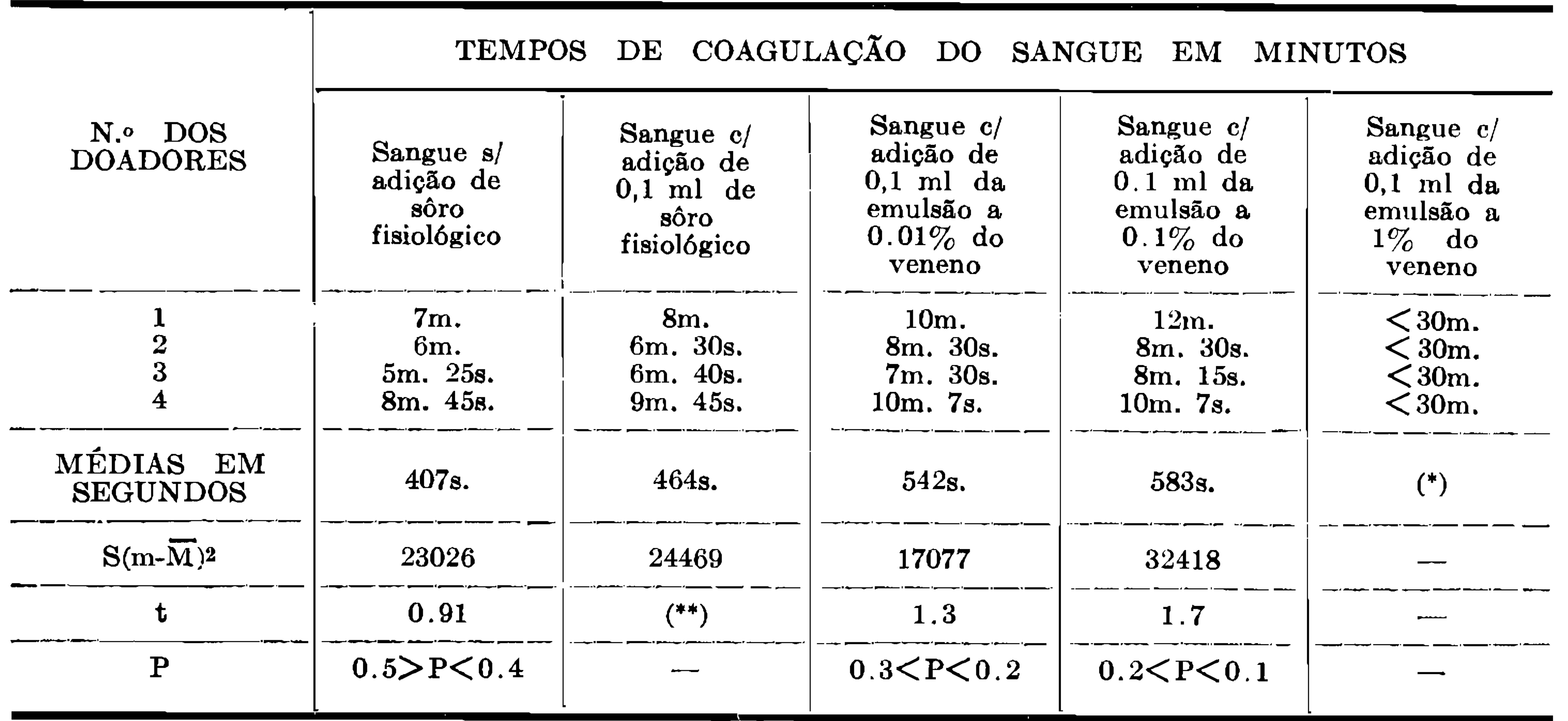

(*) Em face dos expressivos valores obtidos com a emulsão a $1 \%$ (mais de 30 minutos) deixamos de fazer a análise estatística dêstes valores.

(**) A média obtida nestes ensaios, serviu de têrmo de comparação para os demais ensaios.

tados obtidos com o sangue e plasma sanguíneo puros do mesmo doador $(0.5>\mathrm{P}<0.4$ e $\mathrm{P}>0.1)$.

Na Tabela II registramos os resultados referentes aos efeitos produzidos pelas emulsões de curares diferentes no tempo de protrombina do plasma de um só doador. De acôrdo com o que se pode ver, estas emulsões retardaram de maneira significativa $(P<001)$ o tempo de protrombina.

\section{TABELA II}

Efeitos produzidos por emulsões de diferentes curares no tempo de protrombina do plasma humano (exp. "in vitro")

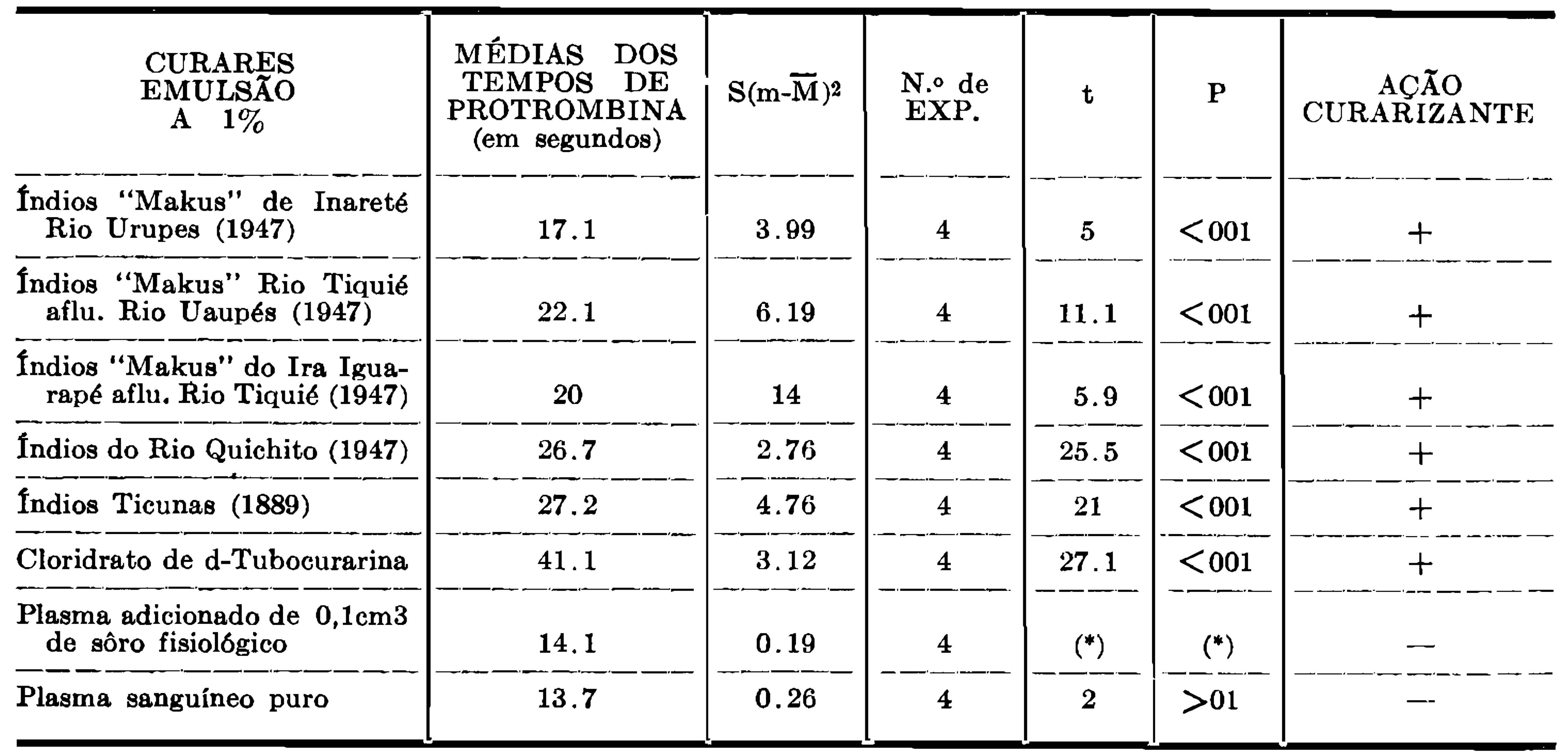

(*) A média obtida nestes ensaios, serviu de têrmo de comparação para os demais. 
Finalmente na Tabela III, a fim de dirimir dúvidas quanto ao comportamento do plasma sanguíneo utilizado nas experiências acima, experimentamos o veneno de Ticunas (emulsão), de mistura com o plasma sanguíneo de quatro doadores diferentes, e os resultados conforme podem ser vistos, foram significativamente diferentes do testemunha isto é, houve também, um aumento significativo $(P<001)$ do tempo de protrombina do plasma sanguíneo dos quatro doadores.

Resumindo, tôdas as emulsões de curares ensaiadas "in vitro", determinaram um aumento do tempo de coagulação do sangue e do tempo de protrombina do plasma sanguíneo.

\section{TABELA III}

Efeitos produzidos pela emulsão de curare preparado por Indios Ticunas no tempo de protrombina do plasma de doadores diferentes

\begin{tabular}{|c|c|c|c|}
\hline $\begin{array}{l}\text { N.o DOS } \\
\text { DOADORES }\end{array}$ & \multicolumn{2}{|c|}{ TEMPOS $\underset{\text { (em segundos) }}{\text { DROTROMBINA }}$} & DIFERENÇAS \\
\hline & $\begin{array}{c}\text { c/adição de } 0,1 \mathrm{ml} \\
\text { da emulsão a } 1 \% \text { do } \\
\text { veneno }\end{array}$ & $\begin{array}{l}\text { c/adicão de } 0,1 \mathrm{ml} \\
\text { de sôro fisiológico }\end{array}$ & \multirow[b]{2}{*}{$\begin{array}{l}+10 \\
+8 \\
+6 \\
+10\end{array}$} \\
\hline $\begin{array}{l}1 \\
2 \\
3 \\
4\end{array}$ & $\begin{array}{l}25 \mathrm{~s} . \\
22 \mathrm{~s} . \\
22 \mathrm{~s} \\
26 \mathrm{~s}\end{array}$ & $\begin{array}{l}15 \mathrm{~s} . \\
14 \mathrm{s.} \\
16 \mathrm{~s} . \\
168 .\end{array}$ & \\
\hline MÉDIAS & $23.7 \mathrm{~s}$. & $15.2 \mathrm{~s}$ & +8.5 \\
\hline $\mathrm{S}(\mathrm{m}-\overline{\mathrm{M}})^{2}$ & 12.76 & 2.76 & 11 \\
\hline $\mathrm{t}$ & \multicolumn{2}{|c|}{8} & 9 \\
\hline $\mathbf{P}$ & \multicolumn{2}{|c|}{$<0.01$} & $<0.01$ \\
\hline
\end{tabular}

\section{COMENTARIOS}

Depois do advento dos célebres experimentos de C. BERnard, os primitivos conceitos que explicavam a maneira pela qual o curare matava os animais com justa razão foram abandonados. Todavia, muito do que foi conjecturado pelos primeiros observadores mereceriam a nosso ver, investigações que quando muito não fôsse, serviriam para esclarecer observações contraditórias que marcaram a sua época.

As cartas de BANCROFT (1) que posteriormente constituíram um compêndio de História Natural, sôbre a recente colônia Inglêsa conquistada na ocasião (G. Inglêsa), assinala a controvérsia que existia quanto à maneira de atuar o veneno dos aborígenes que habitavam o nosso continente.

O seguinte trecho que abaixo transcrevemos do referido livro, focaliza êste assunto: "A few grains, mixed as many ounces of human blood, warm from the veins, interely prevents a separation of serum and crassamentum, and the whole mass continues united in a state of fluidity, similar to that in wich it is drawn, until after some days it putrifies. 
D. Ulloa speaking of the indian arrow-poison, atributes to it a frigorific quality, and says it kills by coagulation the blood. How he came by the knowledge of these particulars, I am uncertain; but De la Condamine no where mentions them; nor did any signs of coagulation ever apear in the fluids of these animals wich have been killed in Europe, with the poison of Lamoes and Ticunas. But if Ulloa says be true, the poison of the Peruvian and Amazonian indians must be different from that of the indians on the coast of Guiana, since the latter rather dissolves than coagulates the blood, as I have discovered by repeated experiments; and that it is not the frigorific".

Os diferentes venenos por nós ensaiados no que diz respeito ao efeito dos mesmos no tempo de coagulação foram coincidentes com as observações de BANCRoFT que acima transcrevemos; todos demonstraram possuir um efeito retardador significativo sôbre o tempo de coagulação do sangue humano in vitro.

C. Bernard ao refutar as observações de Fontana (2) de que o curare não desempenhava nenhuma atividade no tempo de coagulação do sangue, não faz referência, nem mesmo em suas notas inéditas recentemente publicadas (3), quanto à maneira como realizou suas experiências.

B. RodRIGUes entre nós, também cogitou do assunto, e nas notas de aula de Hoenne (4), há uma citação do livro do referido autor de que os nossos aborígenes quando querem potencializar o veneno, lançam mão de uma Menispermacea que não só aumenta o poder curarizante como também, pelo aumento da coagulabilidade que confere ao sangue do animal impedindo-o de sair através a ferida produzida pela seta, determina uma maior absorção do mesmo. Todavia, em que pese às observações do ilustre botânico, os venenos utilizados em nossas presentes experiências, foram obtidos em 1947 e em 1898 e todos ainda possuíam atividades curarizantes e, por outro lado, o efeito no tempo de coagulação também foi constatado e de forma bem ativa com o sal do alcalóide que é encontrado nestas espécies de venenos (d-Tubocurarina).

NESI (6), por sua vez, não obstante a falta de uma análise estatística dos resultados a que chegou, demonstrou que a d-Tubocurarina na dose de $2 \mathrm{mg}$ in vitro aumentava o tempo de coagulação do sangue humano (sòmente 3 dosagens) e que in vivo em doses terapêuticas, produzia uma ligeira diminuição.

Tisthoud (7) em experiências realizadas em cães, observou que a injeção de d-Tubocurarina não alterava significativamente o tempo de coagulação.

KIRCHHOF-UCHIYAMA (5) em experiências sôbre o mesmo assunto em coelhos, chegaram à conclusão de que na primeira hora após a injeção de 1 unidade de Intocostrin o tempo de protrombina aumentava, e que após $24 \mathrm{hs}$. havia em decréscimo, atribuindo tal fato a um possível fator anóxico. 
De conformidade com o que acima abordamos, somos levados a concluir que as afirmações de Bancrcft e de Fontana que remontam há quase dois séculos ainda são válidas, o mesmo ocorrendo com as afirmações de C. Bernard, B. Rodrigues e outros. A nosso ver, a divergência de conceitos, adveio do fato de que os primeiros tiraram as suas conclusões de experiências realizadas in vitro, e os demais de experiências realizadas in vivo. Êste nosso ponto de vista, contraria a hipótese de BANCROFt de que o veneno preparado pelos Ticunas, no que diz respeito ao seu efeito no tempo de coagulação, fôsse diferente dos curares preparados pelos indígenas que habitavam as costas da Guiana Inglêsa, na ocasião.

\section{SUMMARY}

\section{NATURAL CURARES AND d-TUBOCURARINE EFFECTS ON HUMAN BLOOD CLOTHING TIME AND PROTHROMBINE TIME}

In this paper the author points out to a old question of about 200 years ago in wich two kinds of opinions were discussed.

BANCROFT and Fontana in one hand atributes for the indian arrow poison (curare) the propriety of uncoagulate the blood, and C. BERNARD, B. RODRIGUES and others made an contradictory opinion upon this subject.

In our experiments, we utilized 4 curares samples from indians who lives near the Brazilian border at Colombia, the famous Ticunas poison, and the alkaloid d-Tubocurarine. These poisons were added in form of emulsion in saline to the blood and blood plasma in order to perform two kinds of experiments. In one serie of experiments we observed the effect of curare on human blood coagulation time according to LeE-White technic puting $0.5 \mathrm{ml}$ of the various poisons emulsions previously into the tube. By this method, we have found that the emulsion containing $0.1 \mathrm{~g}$ of the poison in $10 \mathrm{ml}$ saline was the most effective (Table II), therefore we used this curare emulsion concentration in the other serie of experiments, in which we tested the action of these venoms on the human blood plasma prothrombine time, (Quick Technic) adding $0.1 \mathrm{ml}$ of the saline poison emulsion to each $0.1 \mathrm{ml}$ of human blood plasma. Results from these experiments can be seen on Table II. These experiments we have tried on one sample of human blood plasma plus the differents curares samples; and in another opportunity four samples of human blood plasma were tried with the curare from Ticunas indians (the most effective in this respect). Results from these experiments may be seen on Table III.

All the poison tried in our experiments was previously tested on toads legs (B. crucifer) to verify his curares action.

All times obtained with the experiments above, show highly significant results $(\mathrm{P}<001)$ when compared with the blood and blood plasma mixed with in the same volume of saline. 
Our results, point out that BANCroft and Fontana views upon the effect of curare on blood clothing time were correct. Curares enhance the blood clothing time "in vitro". But, in other hand, the work in that matter by NesI (6), and Tisthound (7) showing that d-Tubocurarine had no significant effect on blood clothing time of man and dogs "in vivo", made possible to conclude that the observations of C. Bernard, B. Rodrigues and others were also true. These discordance of opinions, we believe, may result as BANCROFT and FonTana researches, were wade "in vitro" whereas C. Bernard, B. Rodrigues and others performed their experiments "in vivo".

\section{REFERENCIAS BIBLIOGRÁFICAS}

1. BANCROFT E. L., 1769, An Essay on Natural History of Guiana in South America, $291 \mathrm{pp}$, London.

2. Bernard C., 1857, Lef̧ons sur les effets Des Substances Toxiques et Medicamenteuses, $396 \mathrm{pp}$, Paris.

3. Grmek M. D., 1966, Notes Inédites de Claud Bernard sur les propriétés physiologiques des poisons de flèches (curare, upas, strychnine et outres) Biol. Medicale, LV, Hors Serie.

4. Hoemne F. C., 1939, Plantas e Substâncias Vegetais Tóxicas e Medicamentosas (Coletânea de 114 aulas) $233 \mathrm{pp}, \mathrm{S}$. Paulo-Rio.

5. Kirchiof, A. C. \& UChiy ama J. K , 1947, Prothrombin time following Curarization. Fed. Proc., 6 (1) : 345, 1947.

6. Nesr J. A., 1951, Accion del Curare sobre la Coagulacion Sanguinea. Rev. Assoc. Med. Argent., 65 (697) : 67-68. 1951.

7. Tisthoud P., 1952, Effect of d-Tubocurarine on Blood Coagulation Time. Anaesthesiology, 13 (6) : 594-598. 